\title{
Acute toxicity of Psilocybe cubensis (Ear.) Sing., Strophariaceae, aqueous extract in mice
}

\author{
Thiago Berti Kirsten, ${ }^{1}$ Maria Martha Bernardi ${ }^{*}, 2$
}

\author{
${ }^{1}$ Centro de Ciências Biológicas e da Saúde, Universidade Presbiteriana Mackenzie, Rua da Consolação, 930, \\ Prédio 12, 01302-907 São Paulo-SP, Brasil, \\ ${ }^{2}$ Centro de Ciências e Humanidades, Universidade Presbiteriana Mackenzie, Rua da Consolação, 930, Prédio 29, \\ 01302-907 São Paulo-SP, Brasil.
}

\begin{abstract}
RESUMO: “Toxicidade aguda do extrato aquoso de Psilocybe cubensis em camundongos”. O Psilocybe cubensis (Ear.) Sing., Strophariaceae, é um cogumelo alucinógeno usado pelos humanos desde a antiguidade, causando diversos efeitos psicóticos. Ele contém dois derivados triptamínicos: psilocibina e psilocina, agonistas do receptor 5-HT2 (serotonina). O objetivo deste trabalho foi investigar os efeitos da administração do extrato aquoso do $P$. cubensis (EAPC) na toxicidade aguda de camundongos. Camundongos Swiss adultos machos e fêmeas receberam o EAPC e foram observados individualmente, diretamente em uma caixa de vidro e em um campo aberto. Com relação ao grupo controle, animais tratados com EAPC apresentaram: aumento de roer, tremores, decréscimo da locomoção e do levantar após 29-38 min e nenhuma alteração na auto-limpeza. Além disso, foram observadas diferenças quanto ao gênero, sendo camundongos fêmeas mais sensíveis que os machos ao EAPC. Foi sugerido que a administração do EAPC leva a alterações específicas no comportamento dos camundongos, característico de drogas que interferem nos sistemas serotoninérgicos e dopaminérgicos centrais. Finalmente, os métodos de observação aqui empregados foram eficientes em avaliar os efeitos tóxicos do extrato.
\end{abstract}

Unitermos: Comportamento, camundongos, psilocina, Psilocybe cubensis, psilocibina, serotonina

\begin{abstract}
Psilocybe cubensis (Ear.) Sing., Strophariaceae, is a hallucinogen mushroom that has been used since the old times by humans, causing several psychotic effects. P. cubensis contains two tryptamine derivates: psilocybin and psilocin, agonists of the 5-HT2 receptor (serotonin). The main objective of this study was to investigate the acute toxicity effects of $P$. cubensis aqueous extract (PCAE) administration in mice. Male and female adult Swiss mice received PCAE $0.1 \mathrm{~mL} / 10 \mathrm{~g}$ i.p., and were observed individually, directly in a glass box and in an open-field. In relation to the data of the control group, PCAE-treated animals presented: an increased gnawing, appearance of wet-dog shakes and a decreased locomotion and rearing frequencies after 29-38 min. Also a clear gender difference was detected, being female mice more sensible to the PCAE than males. It was suggested that PCAE administration produced specific effects on mice behaviors, characteristic of drugs which interfere on central serotonergic and dopaminergic systems. Finally, the observational methods here employed were efficient to evaluate the toxic effects of the extract.
\end{abstract}

Keywords: Behavior, mice, psilocin, Psilocybe cubensis, psilocybin, serotonin.

\section{INTRODUCTION}

Psilocybe cubensis (Ear.) Sing., is a psychedelic mushroom and belongs to the Strophariaceae family which genus contains 144 identified species, among them 81 are psychoactive. $P$. cubensis is one of the easiest mushrooms to cultivate and has very powerful effects as hallucinogen, with the possibility to cause a psychotic outbreak (Guzman, 1983). It contains two psychoactive toxins, derived from the tryptamine and responsible for the mental state change in animals: psilocybin (O-phosphoryl-4-hydroxy-N) and psilocin (4-hydroxy-N, N-dimethyl-tryptamine). These toxins are strongly related with serotonin (5-hydroxytryptamine or 5-HT), an endogenous transmitter of the brain (Schripsema et al., 2003), binding on 5-HT receptors and acting as an agonist on 5-HT2 receptors. In this way, effects are blocked by 5-HT2 antagonist (Vollenweider et al., 1998). Both are indolic alkalis and the main difference is that psilocin is unstable and breaks when dries. Dry mushrooms have action more pronounced than the fresh ones (Diniz, 1999).

The ingestion of the magic mushrooms by humans is known to produce "mind alterations", similar to the LSD (lysergic acid diethylamide, a semi synthetic 
psychedelic drug) effect, however psilocybin is less potent than LSD. The reactions include hallucinations, cardiac, muscular and autonomic alterations (Schwartz \& Smith, 1988; Cuomo et al., 1994; Borowiak et al., 1998).

Psilocin and psilocybin are controlled and classified as hallucinogens pharmacies substances, with great potential of abuse, in the same category of LSD, tetrahydrocannabinol and mescaline (Schripsema et al., 2003). According to the Drugs Act 2005, the magic mushrooms, both fresh and prepared, are classified as a Class A drug. This class of drugs is considered to have the most harm and has the greatest penalty: up to seven years imprisonment in the United Kingdom. Moreover, it is estimated that 2.5-10 g of fresh mushrooms as producing high-dose effects. Whereas there is wide individual variation, the effects of psilocybin generally plateau after around 50 min from consumption, ending approximately 51/2 h later (Riley \& Blackman, 2008).

Despite humans come increasing the use as recreational drug, animal behavioral studies are scarce about the $P$. cubensis effects. This research analyzed and evaluated the acute toxicity effects of the $P$. cubensis aqueous extract (PCAE) administration in mice as a new tool to understand the hallucinogen expression in laboratory animals.

\section{MATERIALS AND METHODS}

\section{Animals}

Forty adult Swiss mice (Mus musculus), males and females, from School of Veterinary Medicine, University of São Paulo were used. Males weighted $39-47 \mathrm{~g}$ and females $32-44 \mathrm{~g}$. Animals were housed in polypropylene cages $(47 \times 27 \mathrm{~cm})$ separated for sex at controlled room temperature $\left(20 \pm 2{ }^{\circ} \mathrm{C}\right)$ on a $12 / 12 \mathrm{~h}$ light-dark cycle (lights on at 6:00 a.m.) with free access to food and water in Mackenzie University facilities. The animals used in this study were maintained in accordance with the guidelines of the Committee on Care and Use of Laboratory Animal Resources of the School of Veterinary Medicine, University of São Paulo, Brazil.

\section{Preparation of the $P$. cubensis aqueous extract}

Psilocybe cubensis (Ear.) Sing., Strophariaceae, was harvested in May 27, 2004, at 8:00-9:00 a.m., from Horto Florestal, in São Paulo, left to dry in stove, and triturated by mechanics expression and used for all experiments. Part of this content was destined to Dra. Vera Lúcia Bononi, from Botany Institute of São Paulo, which performed the microscopical analysis in the hyphae and remaining spores, certifying that mushroom is part of Psilocybe genus. Deionized water $(100 \mathrm{~mL})$ was added to the dried triturated fungus $(1 \mathrm{~g})$ and the solution was warmed per $15 \mathrm{~min}$ at $80{ }^{\circ} \mathrm{C}$. Aqueous extract was filtered in filter-paper and conditioned in dark glass. The effectiveness of the extract was tested previously. PCAE was stocked in refrigerator on $4{ }^{\circ} \mathrm{C}$.

\section{Treatments}

PCAE was intraperitoneally (i.p.) administered in males and females mice at a volume of $0.1 \mathrm{~mL} / 10 \mathrm{~g}$. This dose and preparation were choosing because this is the human consumption form and induces a hallucinogen effect (Stamets, 1978). Control group consisted of male and females mice submitted to the same treatment schedule with control solution i.e., $0.9 \% \mathrm{NaCl}(0.1 \mathrm{~mL} / 10 \mathrm{~g})$.

\section{Behavioral studies}

The acute toxicity tests in our experiments consisted of the toxicity signs and general activity observation in mice after administration of the extract. Evaluation of acute toxicity was performed as Brito (1994) method. The general activity was observed in an open field (Broadhurst, 1960). To minimize the influence of possible circadian changes on behavioral studies, animals were observed at the same time of the day in each session (2:004:00 p.m.).

\section{Evaluation of acute toxicity}

Mice were equally distributed into four groups (control males, control females, experimental males and experimental females), $n=10$ for each group. After the treatments, mice were observed in a glass box (26 x 15 x $18 \mathrm{~cm}$ ), whose walls were of glass fixed in wooden structures, allowing the observation of the animals. For the observations, each mouse was individually placed in the center of the apparatus and the following parameters were measured over a period of 10 min: gnawing frequency (number of gnaw with mouth in the metallic floor and in the wooden structures); wet-dog shakes frequency (number of episodes that the animal shake the body, head and tail); and self-grooming frequency (number of licking or biting of the fur, limbs or genital region). Hand-operated counters were employed to score these behaviors. The observation sections in the glass box were at 0-10, 19-29 and 38-48 min after the PCAE or saline administration.

\section{Open-field studies}

The device used consisted of a round wooden arena (40 cm of diameter, $25 \mathrm{~cm}$ high walls) painted gray subdivided into 25 parts, in a room with mild illumination. For the observations, each mice was individually placed in the center of the apparatus and the following parameters were measured over a period of 9 min: locomotion frequency (number of floor units entered with both feet); and rearing frequency (number of times the animals stood 
on their hind legs). Hand-operated counters were employed to score these behaviors. The device was washed with a $5 \%$ alcohol/water solution before placing the animals, in order to obviate possible biasing effects due to odor clues left by previous rats. The observation sections in the openfield were at 10-19 and 29-38 min after the PCAE or saline administration.

The procedures used in this study are summarized in Figure 1. Glass box and open-field were observed in alternated sessions with the same animals.

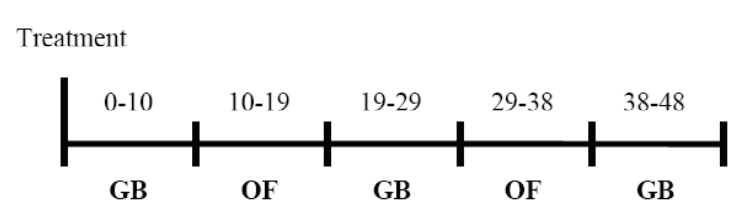

Figure 1. Diagram of the experimental design. GB: glass box; OF: open-field. The observation intervals refer to minutes.

\section{Statistical analysis}

Results were expressed as mean \pm SEM. Threeway ANOVA was used to analyze the data of control and experimental groups, with sex and sessions as the factors. In this case, ANOVA followed by the HolmSidak post-hoc test was also used to compare the homoscedastic data presenting interaction. In all the cases, results were considered significant if $p<0.05$.

\section{RESULTS}

\section{Evaluation of acute toxicity}

Figure 2 shows the results on behavioral parameters of mice treated or not with PCAE. The threeway ANOVA indicated significant differences in gnawing (Figure 2A and B) between treatment $(p<0.001)$ and sex ( $p$ $=0.026)$; no significant differences were detected between sessions $(p=0.265)$. The multiple comparison test showed that gnawing was increased in male $(p=0.001)$ and female $(p=0.028)$ of experimental groups in relation to saline group in all sessions.

Figure 2C and D shows the wet-dog shakes of male and female mice treated or not with PCAE. The three way ANOVA shows significant differences between treatments $(p<0.001)$ and sex $(p<0.017)$ and while no differences were detected between sessions $(p=0.120)$. The multiple comparison test showed that in female, at the 19-29 sessions, this parameter appeared in relation to the data of the control group $(p<0.001)$.

Figure $2 \mathrm{E}$ and $\mathrm{F}$ shows the grooming behavior of mice treated or not with PCAE. No significant differences were detected between treatment $(p=0.077)$, sex $(p=$ $0.299)$ and sessions $(p=0.104)$.

\section{Open-field studies}

Figure 3 shows the results of mice treated or not with PCAE observed in the open field. Three way ANOVA shows significant differences in locomotion between treatments $(p=0.04)$, sex $(p<0.001)$ and sessions $(p<0.001)$. Relative to controls, the multiple comparison test showed a significant decrease in male (Fig. $3 \mathrm{~A}$ ) and in female (Figure 3B) locomotion in the second session $(p=$ 0.029 and $p<0.05$, respectively).

Three way ANOVA shows differences in rearing frequencies between treatments $(p<0.001)$ and sessions $(p<0.001)$ and while no differences were detected between sex $(p<0.19)$ of mice treated or not with PCAE (Figure 3C and D). Relative to controls, the multiple comparison test showed a decreased in male rearing at the second session $(p=0.026)$ and in both sessions in female treated mice $(p<0.001)$.

\section{DISCUSSION}

Present results show that PCAE-treated male mice had an increased gnawing behavior and, despite the absence of statistical significances, it was noted the appearance of wet-dog shakes. The grooming behavior of these animals was not modified. A clear difference was observed between these results and those of female mice. In fact, female mice showed an increased on gnawing and appearance of wet-dog shakes and grooming behavior relative to the respective control group. No deaths were observed, both in male and female mice after the treatment.

According to Vollenweider et al. (1998), the injection of serotonin in rats intensifies gnawing behavior, suggesting that PCAE acts as a serotonin agonist action. In addition, gnawing is a parameter included between those related to aggressiveness in animals (Millan et al., 2000), suggesting that PCAE should acts in aggressive behavior pathways.

It is know that intensive pharmacological activation of central dopaminergic system can engender behavioral stereotypes as gnawing, grooming and licking behaviors. Serotonin containing neurons originating from midbrain raphe nuclei that innervate the substantia nigra pars compacta, pars reticulate and ventral tegmental area, making synaptic contacts with dopaminergic neurons (Meltzer \& Nash, 1991). Likewise, Schmidt et al. (1995) have proposed that 5-HT2A receptors are 'permissive' for stimulated dopamine release. Thus, increases on gnawing behavior in male and female mice could be a consequence of an indirect action of PCAE on dopaminergic striatal pathways via 5-HT2A receptors (Vollenweider et al., 1998; Scalzitti et al., 1999).

The grooming behavior as reported by Robertson et al. (1999) is modulated and dependent of serotonergics projections, which controls the changes of position required by the stereotyped performances of the movements. Therefore, the increased grooming behavior here observed 
also is related to an agonist action of the $P$. cubensis active principles in serotonergic systems. In addition, D1 dopamine receptor activation induces grooming behavior and oral behaviors such as vacuous chewing (Scalzitti et al., 1999). In fact, inactivation of D1 dopamine receptors prevents grooming behavior induced by SKF 38393, a D1 receptor agonist (Wachtel et al., 1992). With this in mind, the increased grooming behavior induced by PCAE in female mice here observed could be derived from an indirect action of the aqueous extract at dopaminergic striatal levels.

PCAE promoted wet-dog shakes in mice in relation to control group. By the way, the wet-dog shake is a behavior in rats or mice know as a quantitative model of central 5-HT activation (Bedard \& Pycock, 1977).
As a matter of fact, Jacobs et al., (1977) and Trulson et al., (1984) reported that, in cats, psilocybin or psilocin administration produce shakings, as much in members as in head, as occurred here. These authors also attribute this effect to an interference with serotonergic activation, reinforcing the hypothesis that PCAE mushroom acts in the serotonergic ways, stimulating them.

Kostowski et al., (1972) show a biphasic effect of psilocybin, in rats and mice, on general activity, causing first excitation followed for a period of motor inhibition. However, in the present investigation it was observed only a decrease, both in locomotion and rearing frequencies. Studies with serotonergics agonists (Hawkins et al., 2002) also indicate that the drugs applied in the animals decrease the exploratory behavior, including locomotion and
Male

a

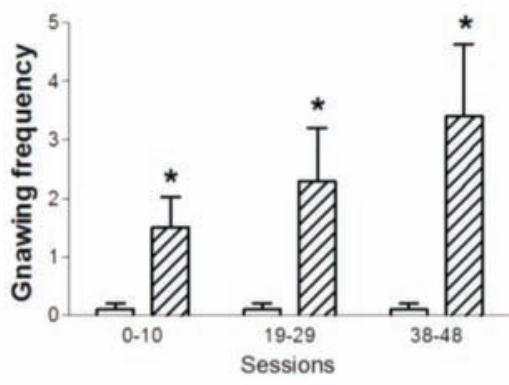

C

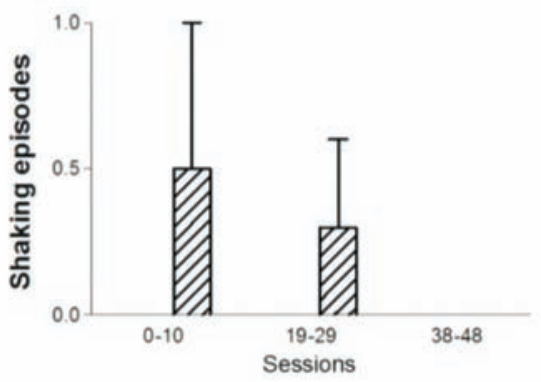

e

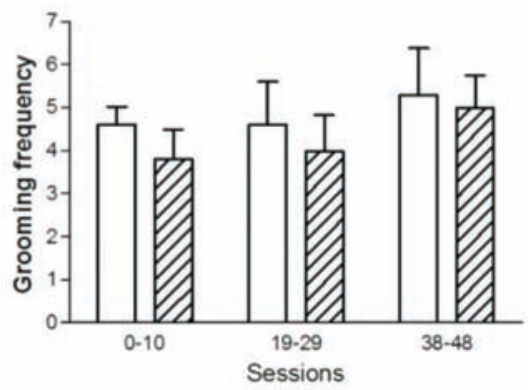

Female

b

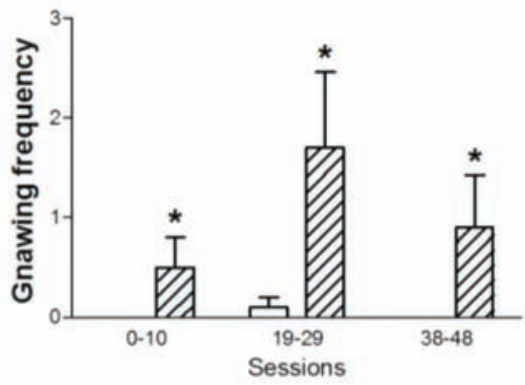

d

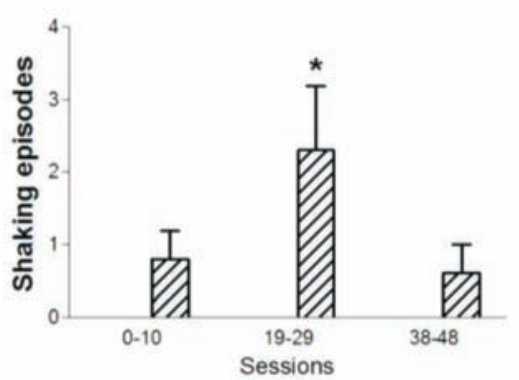

f

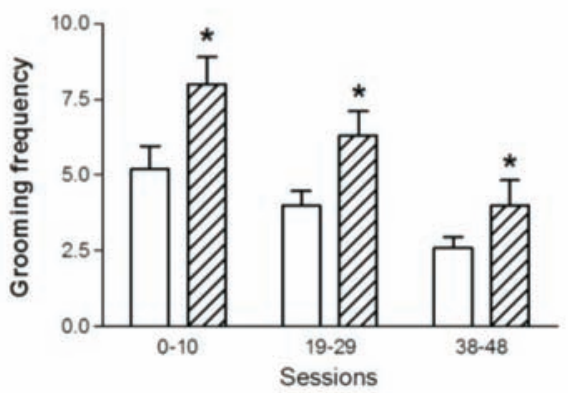

Figure 2. Acute toxic effects of PCAE exposure $(0.1 \mathrm{~mL} / 10 \mathrm{~g})$ on mice behavior at different sessions. Cleared bars = control group; striped bars $=$ experimental group. ${ }^{*} p<0.05$, compared with the control group (three-way ANOVA). The values are represented as mean \pm SEM, $n=10$ for both groups. 


\section{Male}

a

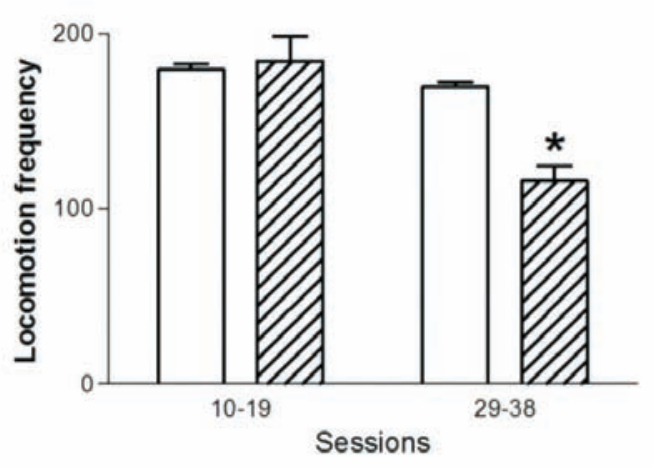

C

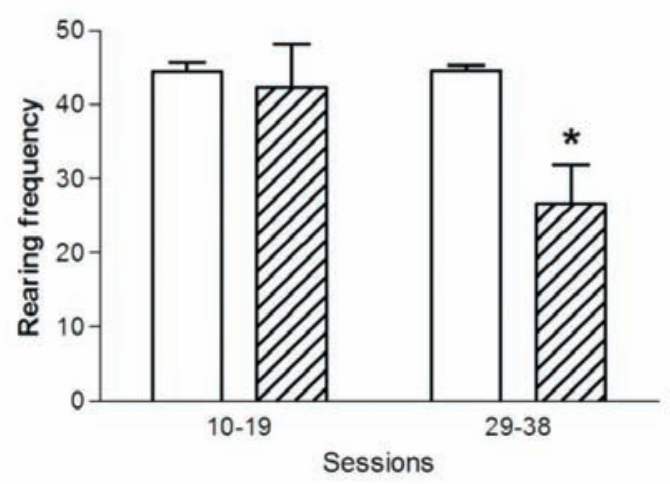

\section{Female}

b

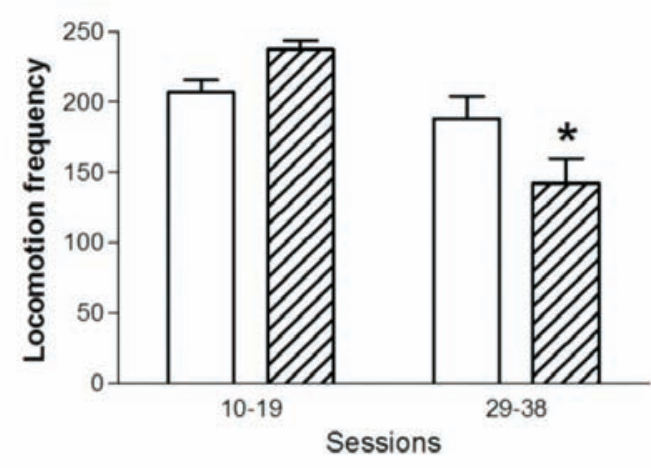

d

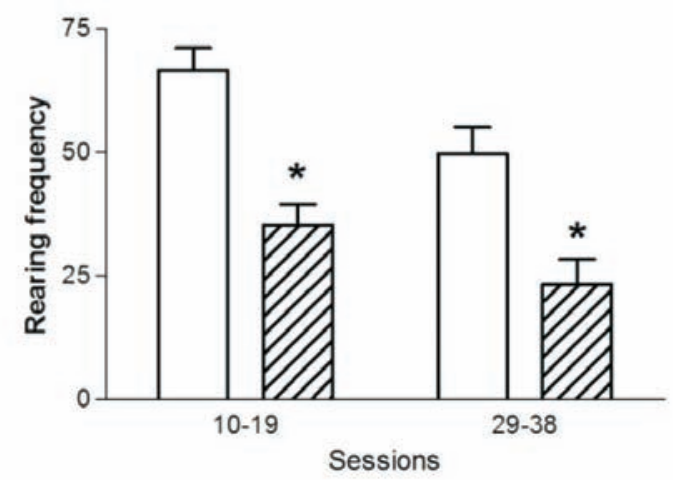

Figure 3. Effects of PCAE exposure $(0.1 \mathrm{~mL} / 10 \mathrm{~g})$ on open-field-behavior of mice at different sessions. Cleared bars = control group; striped bars $=$ experimental group. ${ }^{*} p<0.05$, compared with the control group (three-way ANOVA). The values are represented as mean \pm SEM, $n=10$ for both groups.

rearing behaviors. Therefore, once more, the present data agree that $P$. cubensis extract has a serotonergic agonist like-effect.

Finally, it was observed a greater sensitivity to the extract in female mice than in male mice. Kojima \& Sano (1984) demonstrate that the serotonin acts differently in the two genders, with anatomical differences in male and female brains, in the distributions of serotonergic fibers. Weiss et al. (2005) show different levels of serotonin found in the blood of males and females, beyond genetic differences (synthesis in specific regions of certain chromosomes). Also, male and female mice differences observed on these parameters probably were derived from gender differences between hepatic enzymes activity (Spinosa et al., 2002). These observations could explain the gender differences here observed.

This work showed that PCAE has powerful psychoactive effect, modifying different behaviors parameters in mice, including aggressive episodes, wetdog shakes and decrease on general activity. Also a clear gender difference was detected, being female mice more sensible to the PCAE than males. It was suggested that the extract produced behavioral alterations via activation by the 5 -HT receptors, indirectly modulating the central dopaminergic systems. The model adopted in the applied methodology demonstrated to be of great efficiency in the evaluation of the toxic effects of an extract, being able then to be applied in other studies.

\section{ACKNOWLEDGEMENTS}

This work is part of the graduation monograph of Thiago Berti Kirsten to the Centro de Ciências Biológicas e da Saúde, Universidade Presbiteriana Mackenzie. We thanks to the Veterinary Medicine School, University of São Paulo, for mice donation used in the experiments, to Profa. Dra. Vera Bononi for the mushroom identification and to Flávia Alves and Melina Giorgetti for technical support.

\section{REFERENCES}


Bedard P, Pycock CJ 1977. "Wet-dog" shake behaviour in the rat: a possible quantitative model of central 5-hydroxytryptamine activity. Neuropharmacology 16: 663-670.

Borowiak KS, Ciechanowski K, Waloszczyk P 1998. Psilocybin mushroom intoxication with myocardial infarction. Clin Toxicol 36: 47-49.

Brito AS 1994. Manual de ensaios toxicológicos in vivo. Campinas: Editora UNICAMP, p.15-21.

Broadhurst PL 1960. Experiments in psychogenetics: Applications of biometrical genetics to the inheritance of behaviour. In: Eysenck HJ (ed) Experiments in personality. London: Routledge \& Kegan Paul.

Cuomo MJ, Dyment PG, Gammino VM 1994. Increasing use of "Ecstasy" (MDMA) and other hallucinogens on college campus. J Amer Col Health 42: 271-274.

Diniz OL 1999. Usos, bioquímica e atividade biológica do Psilocybe spp. Monografia em fitoterapia - Instituto Brasileiro de Estudos Homeopáticos, Universidade do Estado do Rio de Janeiro.

Guzmán G 1983. The Genus Psilocybe: A Systematic Revision of the Known Species Including the History, Distribution and Chemistry of the Hallucinogenic Species. J. Cramer, Vaduz: Beihefte zur Nova Hedwigia 74.

Hawkins MF, Uzelac SM, Baumeister AA, Hearn JK, Broussard JI, Guillot TS 2002. Behavioral responses to stress following central and peripheral injection of the 5-HT2 agonist DOI. Pharmacol Biochem Behav 73: 537-544.

Jacobs BL, Trulson ME, Stern WC 1977. Behavioral effects of LSD in the cat: proposal of an animal behavior model for studying the actions of hallucinogenic drugs. Brain Res 132: 301-314.

Kojima M, Sano Y 1984. Sexual differences in the topographical distribution of serotonergic fibers in the anterior column of rat lumbar spinal cord. Anat Embryol 170: 117-121.

Kostowski W, Rewerski W, Piechocki T 1972. II. The effects of some hallucinogens on aggressiveness of mice and rats. Pharmacology 7: 259-263.

Meltzer HY, Nash JF 1991. Effects of antipsychotic drugs on serotonin receptors. Pharmacol Rev 43: 587-604.

Millan MJ, Brocco M, Rivet JM, Audinot V, Newman-Tancredi A, Maiofiss L, Queriaux S, Despaux N, Peglion JL, Dekeyne A 2000. S18327 (1-\{2-[4-(6-Fluoro-1,2-benzisoxazol3-yl)piperid-1-yl]ethyl\}3-phenyl imidazolin-2-one), a novel, potential antipsychotic displaying marked antagonist properties at 1- and 2-adrenergic receptors: II. Functional profile and a multiparametric comparison with haloperidol, clozapine, and 11 other antipsychotic agents. J Pharmacol Exp Ther 292: 54-66.

Riley SC, Blackman G 2008. Between prohibitions: patterns and meanings of magic mushroom use in the UK. Subst Use Misuse 43: 55-71.

Robertson BJ, Boon F, Cain DP, Vanderwolf CH 1999. Behavioral effects of anti-muscarinic, anti-serotonergic, and antiNMDA treatments: hippocampal and neocortical slow wave electrophysiology predict the effects on grooming in the rat. Brain Res 838: 234-240.

Scalzitti JM, Cervera LS, Smith C, Hensler JG 1999. Serotonin2A receptor modulation of D1 dopamine receptor-mediated grooming behavior. Pharmacol Biochem Behav 2: 279284.

Schmidt CJ, Sorensen SM, Kehne JH, Carr AA, Palfreyman MG
1995. The role of 5-HT2A receptors in antipsychotic activity. Life Sci 56: 2209-2222.

Schripsema J, Dagnino D, Gosmann G 2003. Alcalóides indólicos. In: Simões CMO, Schenkel EP, Gosmann G, Mello JCP, Mentz LA, Petrovick PR (eds) Farmacognosia: da planta ao medicamento. 5.ed. Porto Alegre: UFRGS, p.819-946.

Schwartz RH, Smith D 1988. Hallucinogenic mushrooms. Clin Pediatr 27: 70-73.

Spinosa HS, Górniak SL, Bernardi MM 2002. Farmacologia aplicada à medicina veterinária. Rio de Janeiro: Guanabara Koogan, p.193-201.

Stamets P 1978. Psilocybe mushrooms and their allies. Seattle: Homestead Book Co.

Trulson ME, Preussler DW, Trulson VM 1984. Differential effects of hallucinogenic drugs on the activity of serotonincontaining neurons in the nucleus centralis superior and nucleus raphe pallidus in freely moving cats. $J$ Pharmacol Exp Ther 228: 94-102.

Vollenweider FX, Vollenweider-Scherpenhuyzen MF, Babler A, Vogel H, Hell D 1998. Psilocybin induces schizophrenialike psychosis in humans via a serotonin-2 agonist action. NeuroReport 9: 3897-3902.

Wachtel SR, Brooderson RJ, White FJ 1992. Parametric and pharmacological analyses of the enhanced grooming response elicited by the D1 dopamine receptor agonist SKF 38393 in the rat. Psychopharmacology 109: 41-48.

Weiss LA, Abney M, Cook EH Jr, Ober C 2005. Sex-specific genetic architecture of whole blood serotonin levels. Am J Hum Genet 76: 33-41. 